\section{Fatal Anthrax Pneumonia in Welders and Other Metalworkers Caused by Bacillus cereus Group Bacteria Containing Anthrax Toxin Genes - U.S. Gulf Coast States, 1994-2020}

Patrick Dawson, $\mathrm{PhD}^{1,2, *}$; Caroline A. Schrodt, $\mathrm{MD}^{1,2, *}$; Karl Feldmann, MS ${ }^{3}$; Rita M. Traxler, $\mathrm{PhD}^{1}$; Jay E. Gee, $\mathrm{PhD}^{1}$; Cari B. Kolton, $\mathrm{MS}^{1}$; Chung K. Marston ${ }^{1}$; Christopher A. Gulvik, $\mathrm{PhD}^{1}$; James M. Antonini, $\mathrm{PhD}^{3}$; María E. Negrón, DVM, PhD ${ }^{1}$; John R. McQuiston, $\mathrm{PhD}^{1}$; Kate Hendricks, $\mathrm{MD}^{1}$; Zachary Weiner, $\mathrm{PhD}^{1}$; Gary A. Balsamo, $\mathrm{DVM}^{4}$; Theresa Sokol, MPH ${ }^{4}$; Paul Byers, MD ${ }^{5}$; Kathryn Taylor, $\mathrm{MD}^{5}$; Saad Zaheer, $\mathrm{MD}^{6}$; Stephen Long, $\mathrm{MD}^{7}$;

Briana O'Sullivan, $\mathrm{MPH}^{8}$; Marie A. de Perio, $\mathrm{MD}^{3}$; Alex R. Hoffmaster, $\mathrm{PhD}^{1}$; Johanna S. Salzer, DVM, PhD ${ }^{1}$; William A. Bower, $\mathrm{MD}^{1}$

In 2020, CDC confirmed two cases of pneumonia (one fatal) in welders caused by rare Bacillus cereus group bacteria containing anthrax toxin genes typically associated with Bacillus anthracis. B. cereus group bacteria are gram-positive facultative anaerobes, often toxin-producing, that are ubiquitous in the environment and reside naturally in soil and dust (1). B. cereus can also be found in food, and although infection typically causes illnesses characterized by diarrhea or vomiting, B. cereus can have other clinical manifestations (e.g., pulmonary, ocular, or cutaneous). Among seven persons in the United States reported to be infected with $B$. cereus group bacteria containing anthrax toxin genes resulting in pneumonia since 1994, five patients died and two had critical illness with prolonged hospitalization and recovery $(2-5)$. All persons with pneumonia were welders or other metalworkers who had worked in Louisiana or Texas (Table). In addition to the seven pneumonia cases, a cutaneous infection with $B$. cereus group bacteria containing anthrax toxin genes has been reported in a patient with an anthrax eschar in Florida. ${ }^{\dagger}$

Understanding the extent to which Bacillus species other than $B$. anthracis carry anthrax toxin genes and whether their geographic range extends beyond the U.S. Gulf Coast states is limited. Furthermore, little is known about why these highly fatal pneumonia cases have only been detected among welders and other metalworkers. Long-term exposure to welding and

\footnotetext{
*These authors contributed equally to this report.

${ }^{\dagger}$ https://journals.plos.org/plosone/article?id=10.1371/journal.pone. 0156987
}

metalworking fumes is associated with various forms of lung injury that can cause changes in lung function and increase susceptibility to pulmonary infections, including fatal pneumonia. ${ }^{\S}$ An investigation by $\mathrm{CDC}$ at one patient's worksite in Louisiana (patient F) identified a bacterial isolate in a soil sample that genetically matched a clinical isolate from the patient. However, it is unclear why only one person at each worksite became ill and what environmental or host risk factors might have facilitated the exposure and infection.

Several actions can decrease risk for lung injury or infection, including anthrax pneumonia caused by $B$. cereus group bacteria, among welders and other metalworkers. Because of the association between welding or metalworking and pulmonary infections or injury, it is important that employers educate workers regarding hazards associated with welding and measures they can take to minimize potential exposures. Welding and metalworking employers, trade associations, and unions might consider targeted outreach to increase workers' awareness about pulmonary infections, including anthrax, especially those workers in the U.S. Gulf Coast states. In addition, employers should conduct a hazard assessment at worksites and consider the use of National Institute for Occupational Safety and Health-approved respirators as part of a written respiratory protection program.9,**

Clinicians should consider $B$. cereus group bacteria in the differential diagnosis when treating welders and other metalworkers with severe, rapidly progressive pneumonia or other anthrax-like disease. ${ }^{\dagger \dagger}$ B. cereus group bacteria identified on culture are not always contaminants; when $B$. cereus with anthrax toxin is suspected, laboratorians and clinicians should pursue additional testing through their state Laboratory Response Network laboratory. ${ }^{\$ \$}$ Regional health departments and the Laboratory Response Network serve pivotal roles in pathogen detection and procuring anthrax antitoxin for confirmed cases.

\footnotetext{
$\$$ https://www.sjweh.fi/article/625; https://www.tandfonline.com/doi/ abs/10.1080/713611032

Occupational Safety and Health Administration. 29 CFR Sect. 1910.134. https://www.osha.gov/enforcement/directives/cpl-02-02-054

** https://www.cdc.gov/niosh/npptl/topics/respirators/disp_part/respsource.html

t† https://www.cdc.gov/anthrax/treatment/index.html

$\mathbb{S}$ https://emergency.cdc.gov/lrn/
} 
TABLE. Characteristics of patients with severe anthrax pneumonia caused by non-Bacillus anthracis infections* with Bacillus cereus group bacteria containing anthrax toxin genes - Louisiana and Texas, 1994-2020

\begin{tabular}{|c|c|c|c|c|c|c|c|}
\hline Patient & Year & Work location & Strain ${ }^{\dagger}$ & Age, yrs & Sex & Occupation & Outcome \\
\hline$\overline{A^{\S}}$ & 1994 & Louisiana & B. cereus G9241** & 42 & Male & Weldert† & Recovered \\
\hline$B^{\S}$ & 2003 & Texas & B. cereus $03 \mathrm{BB} 87^{* *}$ & 56 & Male & Metalworker & Died \\
\hline$C^{\S}$ & 2003 & Texas & B. cereus $03 \mathrm{BB} 102$ & 39 & Male & Welder & Died \\
\hline$D^{\S \S}$ & 2007 & Louisiana & B. cereus LA2007** & 47 & Female & Metalworker & Died \\
\hline Eๆๆ & 2011 & Texas & B. cereus Elc2 & 39 & Male & Welder & Died \\
\hline $\mathrm{F}$ & 2020 & Louisiana*** $^{* *}$ & B. cereus LA2020** & 39 & Male & Welder & Recovered ${ }^{\dagger+\dagger}$ \\
\hline G & 2020 & Texas & B. cereus TX2020 & 34 & Male & Welder & Died \\
\hline
\end{tabular}

* Excludes laboratory-acquired infections.

† Strain names are from original reported designations. Previous strain name assignments might not reflect current classifications.

$\S$ https://academic.oup.com/cid/article/44/3/414/314305

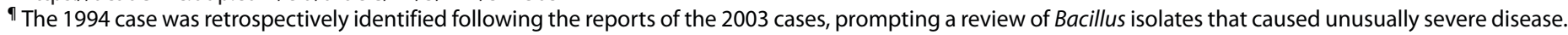
https://www.pnas.org/content/101/22/8449

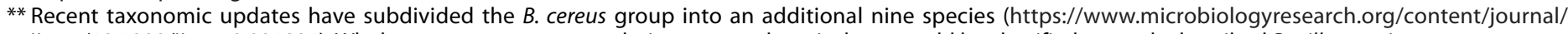
ijsem/10.1099/ijsem.0.001821). Whole genome sequence analysis suggests these isolates would be classified as newly described Bacillus tropicus.

t† Welders, a subset of metalworkers, are listed separately because five of the seven patients were welders.

$\S \S$ https://journals.asm.org/doi/10.1128/genomeA.00181-17

ๆๆ https://meridian.allenpress.com/aplm/article/135/11/1447/64984/

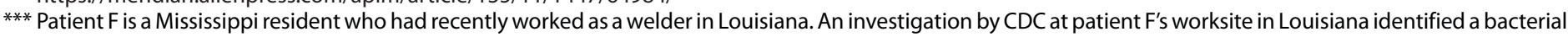
isolate in a soil sample that genetically matched a clinical isolate from patient $F$.

t†† Patient $F$ received anthrax antitoxin.

Corresponding author: William A. Bower, wab4@cdc.gov, 404-639-0376.

\begin{abstract}
${ }^{1}$ Division of High-Consequence Pathogens and Pathology, National Center for Emerging and Zoonotic Infectious Diseases, CDC; ${ }^{2}$ Epidemic Intelligence Service, CDC; ${ }^{3}$ National Institute for Occupational Safety and Health, CDC; ${ }^{4}$ Louisiana Department of Health; ${ }^{5}$ Mississippi State Department of Health; ${ }^{6}$ Harris County Public Health, Houston, Texas; ${ }^{7}$ Houston Health Department, Houston, Texas; ${ }^{8}$ Texas Department of State Health Services, Austin, Texas.
\end{abstract}

All authors have completed and submitted the International Committee of Medical Journal Editors form for disclosure of potential conflicts of interest. No potential conflicts of interest were disclosed.

\section{References}

1. Turnbull PC. Bacillus [Chapter 15]. In: Baron S, ed. Medical microbiology. 4th ed. Galveston, TX: University of Texas Medical Branch at Galveston; 1996.

2. Hoffmaster AR, Ravel J, Rasko DA, et al. Identification of anthrax toxin genes in a Bacillus cereus associated with an illness resembling inhalation anthrax. Proc Natl Acad Sci U S A 2004;101:8449-54. PMID:15155910 https://doi.org/10.1073/pnas.0402414101

3. Avashia SB, Riggins WS, Lindley C, et al. Fatal pneumonia among metalworkers due to inhalation exposure to Bacillus cereus Containing Bacillus anthracis toxin genes. Clin Infect Dis 2007;44:414-6. PMID:17205450 https://doi.org/10.1086/510429

4. Wright AM, Beres SB, Consamus EN, et al. Rapidly progressive, fatal, inhalation anthrax-like infection in a human: case report, pathogen genome sequencing, pathology, and coordinated response. Arch Pathol Lab Med 2011;135:1447-59. PMID:21882964 https://doi. org/10.5858/2011-0362-SAIR.1

5. Pena-Gonzalez A, Marston CK, Rodriguez-R LM, et al. Draft genome sequence of Bacillus cereus LA2007, a human-pathogenic isolate harboring anthrax-like plasmids. Genome Announc 2017;5:e00181-17. PMID:28428293 https://doi.org/10.1128/genomeA.00181-17 